\title{
Editorial
}

\section{Resilience and Global Sustainability}

\author{
$\underline{\text { Carl Folke }}^{1,2}$ and Lance Gunderson $^{3}$
}

\section{INTRODUCTION}

On 9 August 2010, Mr. Ban Ki-moon, the UN Secretary-General, launched a High-level Panel on Global Sustainability (GSP). This is an initiative following the path of the Brundtland Commission on sustainable development and its report Our Common Future, a key document for the milestone Rio conference on environment and development in 1992. The Brundtland Commission was chaired by the Prime Minister of Norway at the time, Mrs. Gro Harlem Brundtland. The new high-level panel is co-chaired by the President of Finland, Mrs. Tarja Halonen, and the President of South Africa, Mr. Jacob Zuma.

Following is a quote from the terms of reference:

Increasing strains and crises in recent years point to the deterioration of the natural environment. The changing climate is one key manifestation. We are reaching, and increasingly overstepping, planetary boundaries. Efforts to reach the Millennium Development Goals and other social and economic targets are hampered by the inability to agree on decisive and coordinated action in national and multilateral fora. This reveals the weaknesses of our governance structures and our outdated development models. It shows the limits of our current approach, which continues to deal with individual symptoms rather than the causes and their interrelationships.

But what is global sustainability about? The Ecological Society of America launched an effort referred to as Planetary Stewardship for global sustainability (Power and Chapin 2009), and The International Council for Science (ICSU) initiated a consultation process to help in identifying how to remove critical barriers impeding progress toward global sustainability, which resulted in their identification of five Grand Challenges for Earth system science (Reid et al. 2010, see also Leemans et al. 2009).

- Improve the usefulness of forecasts of future environmental conditions and their consequences for people.

- Develop, enhance, and integrate observation systems to manage global and regional environmental change.

- Determine how to anticipate, avoid, and manage disruptive global environmental change.

- Determine institutional, economic, and behavioral changes to enable effective steps toward global sustainability.

- Encourage innovation, and mechanisms for evaluation, in technological, policy, and social responses to achieve global sustainability.

Last year, Ecology and Society published an article on planetary boundaries, a sister article to a shorter version in Nature (Rockström et al. 2009a,b), reflecting the dynamic preconditions of the biosphere for a prosperous development of human societies. Within less than a year, the planetary boundaries concept has reached international policy efforts as witnessed in the quote above. Also, work on social-ecological systems and integrated science for resilience and sustainability, the focus of this journal, is truly escalating worldwide, witnessed, for example, in millions of hits on search engines.

It is in the context of integrative science that we are really pleased to be editors of Ecology and Society. We are not specializing into a well-defined niche within a well-defined discipline. We are exploring, experimenting, and encouraging publication of 
work that takes us into new terrain, that not only generates information and knowledge, but that helps us understand the complex nature of intertwined social-ecological systems in the context of resilience and sustainability at all scales and across them.

\section{THIS ISSUE}

We are pleased to present several such contributions among the over 80 articles published in the final two issues of 2010 in Ecology and Society. Among the regular features, we include some 57 research articles, 11 synthesis articles, five responses to previous articles, seven insight articles, and one commentary. Topics cover a range of ecosystems and social settings from local to global. They discuss success and failures in resource management of fisheries, water and biodiversity conservation, and they cover marine and terrestrial as well as urban and rural challenges, land use change, and underlying drivers. Several deal with ecosystem services and their values, and studies on institutions, networks, adaptive comanagement, and governance are well represented. Others are about collaboration, learning, participation, perceptions and meanings, and diverse knowledge systems. Many focus on resilience and vulnerability, transitions and transformations, and some are inspired by the adaptive cycle and panarchy as integrated parts of the analysis. The cases span from archeological sites to current ecosystem management with examples from many different continents. We again note the strong linkages between the ecological and social components across these scales and issues.

Our special features continue to be a hallmark of the journal, and note that 39 of the published articles (research, insight, and synthesis) were part of a special feature. We highlight the contributions of three special features that are now finalized. The first is titled Catastrophic Thresholds: Perspectives, Definitions and Applications, edited by Robert A. Washington-Allen, David D. Briske, and Herman H. Shugart, and presents a number of outstanding articles that summarize current understanding on nonlinearities in complex ecological and social systems. The second is the feature edited by Graeme Cumming on Risk Mapping for Avian Influenza: a Social-Ecological Problem, and argues for a more holistic integration of people and nature in confronting issues of disease, while drawing on half a dozen examples from around the world. The third, edited by Beatrice Crona and Klaus Hubacek, focuses on Social Network Analysis in Natural Resource Governance and asks how social networks lubricate the machinery of natural resource and ecosystem governance. The seven excellent articles look at networks in relation to issues such as agency and power, informal and formal structures, collaboration, and adaptive comanagement.

All those efforts contribute bits and pieces to a deeper understanding of how the local, the regional, and global interact now and also through time. Clearly, we are in a new situation where human actions not only shape local and regional environments but also the global, hence the planetary boundaries and the challenge of global sustainability.

We have called this editorial 'Resilience and Global Sustainability.' Contributions among the set of papers raise the challenge of multiscale interactions and collaborations in this context. One of them on resilience thinking connects resilience to global sustainability by arguing that the relatively stable basin of attraction of the last 10,000 years, within which agriculture and human civilizations have largely developed and flourished, is where we would like to remain. However, it will require that societies seriously consider ways to explore options for deliberate transformation of social-ecological systems at local and regional scales and across scales that erode Earth System resilience and instead foster those that contribute to global sustainability.

Responses to this article can be read online at: http://www.ecologyandsociety.org/voll5/iss4/art43/ responses/

\section{Acknowledgments:}

We wish to close the 15th issue of Ecology and Society with thanks to all of the staff, editors, reviewers, authors, and readers who give of their time and efforts to produce the journal. We believe strongly that the work that emerges from the journal is helping find a way to a more resilient and sustainable planet. We appreciate your efforts on this collective endeavor. 


\section{LITERATURE CITED}

Leemans, R., G. Asrar, A. Busalacchi, J. Canadell, J. Ingram, A. Larigauderie, $\mathbf{H}$. Mooney, C. Nobre, A. Patwardhan, M. Rice, F. Schmidt, S. Seitzinger, H. Virji, C. Vörösmarty, and O. Young. 2009. Developing a common strategy for integrative global environmental change research and outreach: the Earth System Science Partnership (ESSP). Current Opinion in Environmental Sustainability 1:4-13.

Power, M. E., and F. S. Chapin, III. 2009. Planetary stewardship. Frontiers in Ecology and the Environment 7(8):399.

Reid, W. V., D. Chen, L. Goldfarb, H. Hackmann, Y. T. Lee, K. Mokhele, E. Ostrom, K. Raivio, J. Rockström, H. J. Schellnhuber, and A. Whyte. 2010. Earth system science for global sustainability: grand challenges. Science 330:916-917.

Rockström, J., W. Steffen, K. Noone, Å. Persson, F. S. Chapin, III, E. F. Lambin, T. M. Lenton, M. Scheffer, C. Folke, H. J. Schellnhuber, B. Nykvist, C. A. de Wit, T. Hughes, S. van der Leeuw, H. Rodhe, S. Sörlin, P. K. Snyder, R. Costanza, U. Svedin, M. Falkenmark, L. Karlberg, R. W. Corell, V. J. Fabry, J. Hansen, B. Walker, D. Liverman, K. Richardson, P. Crutzen, and J. A. Foley. 2009a. A safe operating space for humanity. Nature 461:472-475.

Rockström, J., W. Steffen, K. Noone, А̊. Persson, F. S. Chapin, III, E. Lambin, T. M. Lenton, M. Scheffer, C. Folke, H. Schellnhuber, B. Nykvist, C. A. De Wit, T. Hughes, S. van der Leeuw, $H$. Rodhe, S. Sörlin, P. K. Snyder, R. Costanza, U. Svedin, M. Falkenmark, L. Karlberg, R. W. Corell, V. J. Fabry, J. Hansen, B. Walker, D. Liverman, K. Richardson, P. Crutzen, and J. Foley. 2009b. Planetary boundaries: exploring the safe operating space for humanity. Ecology and Society 14(2): 32. [online] URL: http://www.ecolog yandsociety.org/vol14/iss2/art32/ 